\title{
PENGARUH PENDIDIKAN DAN PELATIHAN PENGUATAN KEPALA SEKOLAH DAN IKLIM SEKOLAH TERHADAP KINERJA GURU DI SEKOLAH DASAR KECAMATAN WINONG
}

\author{
Kaswi $^{1}$, Gunawan Setiadi ${ }^{2}$, dan Su`ad ${ }^{3}$ \\ 1,2,3 Universitas Muria Kudus, Kudus, Indonesia \\ ${ }^{1}$ kaswibinlasmin@gmail.com, ${ }^{2}$ gunawan.setiadi@umk.ac.id, ${ }^{3}$ suad@umk.ac.id
}

\begin{abstract}
ABSTRAK
Penelitian ini dilatarbelakangi oleh rendahnya kinerja guru karena kurangnya pendidikan dan pelatihan penguatan kepala sekolah dan kurang menjaga iklim sekolah Permasalahan dalam penelitian ini adalah: 1) Seberapa besar pengaruh pendidikan dan pelatihan penguatan kepala sekolah terhadap kinerja guru pada Sekolah Dasar Neger di Kecamatan Winong, Kabupaten Pati?, 2) Seberapa besar pengaruh iklim sekolah terhadap kinerja guru pada Sekolah Dasar Negeri di Kecamatan Winong, Kabupaten Pati? 3) Seberapa besar pengaruh pendidikan dan pelatihan penguatan kepala sekolah dan iklim sekolah secara bersama - sama terhadap kinerja guru pada Sekolah Dasar Negeri di Kecamatan Winong, Kabupaten Pati? Pendekatan yang digunakan dalam penelitian ini adalah kuantitatif, Jenis penelitian korelasional atau mencari pengaruh antara variabel bebas pendidikan dan pelatihan penguatan kepala sekolah $\left(\mathrm{X}_{1}\right)$ dan iklim sekolah $\left(\mathrm{X}_{2}\right)$, dengan variabel terikat: kinerja guru (Y). Penelitian ini dilaksanakan pada bulan Juli sampai Agustus 2020 di 40 Sekolah Dasar Negeri di Kecamatan Winong. Jumlah populasi 267 dan sampel 160 dipilih secara acak. Teknik pengumpulan data menggunakan angket. Uji Persyaratan menggunakan uji normalitas, uji homogenitas,uji linieritas dan uji multikolinieritas. Rencana hasil penelitian diuji menggunakan uji analisis regresi linier sederhana, uji t, analisis regresi linier berganda yang diolah menggunakan program SPSS. Dari olah data diketahui data berdistribusi normal, homogen, linier dan tidak multikolinier. Dari uji hipotesis ditemukan: 1). terdapat hubungan variabel $\mathrm{X}_{1}$ terhadap $\mathrm{X}_{2}$ dengan persamaan $\mathrm{Y}=71.661+0.632 \mathrm{X}_{1}$ diterima kebenarannya. Artinya setiap kenaikan satu pendidikan dan pelatihan penguatan kepala sekolah akan menaikkan kinerja guru sebesar 0.632 pada konstanta 71.661 , kekuatan korelasi sebesar 0.685. Besarnya kontribusi variabel $\mathrm{X}_{1}$ terhadap $\mathrm{Y}$ sebesar $89.6 \%, 2$ ). terdapat hubungan variabel $\mathrm{X}_{2}$ terhadap $\mathrm{Y}$ dengan persamaan $\mathrm{Y}=71.661+0.495 \mathrm{X}_{2}$ Kekuatan korelasinya sebesar 0.697 dengan kontribusi $74.4 \%, 3$ ). terdapat hubungan positif antara pendidikan dan pelatihan penguatan kepala sekolah dan iklim sekolah terhadap kinerja guru yang dinyatakan dengan persamaan $\hat{\mathrm{Y}}=71.661+0.632 \mathrm{X}_{1}+0.495 \mathrm{X}_{2}$. Kekuatan korelasinya sebesar 0.707 . Kontribusi variabel $\mathrm{X}_{1}$ dan $\mathrm{X}_{2}$ terhadap $\mathrm{Y}$ sebesar $79,6 \%$, sedangkan $20,4 \%$ dipengaruhi oleh faktor yang lain.
\end{abstract}

Kata Kunci: pendidikan dan pelatihan penguatan kepala sekolah

\section{THE INFLUENCE OF EDUCATION AND TRAINING TO STRENGTHEN THE SCHOOL PRINCIPALS AND THE SCHOOL CLIMATE ON TEACHERS' PERFORMANCE AT ELEMENTARY SCHOOLS IN WINONG DISTRICTS}

\section{ABSTRACT}

This research was motivated by the low performance of teachers due to the lack of education and training to strengthen school principals and the lack of maintaining the school climate. The problems in this research were: 1) the influence of education and training to strengthen school principals on teachers' performance at Public Elementary Schools in Kecamatan Winong, Kabupaten Pati, 2) the influence of school climate on teachers' performance at Public Elementary Schools in Kecamatan Winong, Kabupaten Pati, 3) the influence of education and training to strengthen school principals and school climate to affect the teachers' performance at Public Elementary Schools in Kecamatan Winong, Kabupaten Pati. This research was quantitative research with a correlational study that sought for the influence between the independent variables of education and school principal strengthening training $\left(X_{1}\right)$ and school climate $\left(X_{2}\right)$, with the dependent variable: teachers' performance $(Y)$. This research was conducted from July to August 2020 at 40 Public Elementary Schools in Kecamatan Winong. The total population was 267 and 160 samples were randomly selected. The data were collected through a questionnaire. The requirements tests used were the normality test, homogeneity test, linearity test, and multicollinearity test. The research plan was tested by using simple linear regression analysis, $t$-test, multiple linear regression analysis processed using the SPSS program. The result found that the data were normally distributed, homogeneous, linear, and not multicollinear. Then, the result of the hypothesis test found: 1) there was a relationship between the variable $X_{1}$ and $X_{2}$ with the equation of $Y=71.661+0.632 X 1$; thus, the hypothesis was accepted. This means that every increase in education and strengthening training for principals increased teachers' performance by 0.632 at a constant of 71.661 . The strength of the correlation was 0.685 . The amount of contribution of variable $X_{1}$ to $Y$ equals $89.6 \%$; 2 ) there was a relationship between variable $X_{2}$ and $Y$ with the equation of $Y=71.661+0.495 X 2$. The strength of the correlation was 0.697 with a contribution of $74.4 \%$; 3 ) there was a positive relationship between education and training to strengthen principals and school climate on teachers' performance which was expressed by the equation of $Y$ $=71.661+0.632 X_{I}+0.495 X_{2}$. The correlation score was 0.707 . The contribution of variables $X_{1}$ and $X_{2}$ to $Y$ was $79.6 \%$, while $20.4 \%$ was influenced by other factors.

Keywords: school principal strengthening education and training

\begin{tabular}{|c|c|c|}
\hline Submitted & Accepted & Published \\
\hline 14 Februari 2021 & 05 September 2021 & 18 November 2021 \\
\hline
\end{tabular}

\begin{tabular}{|l|c|c|c|}
\hline Citation & $:$ & $\begin{array}{r}\text { Kaswi, K., Setiadi, G., \& Su`ad, S. (2021). Pengaruh Pendidikan dan Pelatihan Penguatan Kepala Sekolah Dan Iklim } \\
\text { Sekolah Terhadap Kinerja Guru Di Sekolah Dasar Kecamatan Winong. Jurnal PAJAR (Pendidikan dan } \\
\text { Pengajaran), 5(6), 1536-1543. DOI : http://dx.doi.org/10.33578/pjr.v5i6.8318. }\end{array}$ \\
\hline
\end{tabular}




\section{PENDAHULUAN}

Kepala sekolah menjadi aktor utama yang mengelola masukan (input), proses, dan keluaran (output) dengan berpedoman pada Standar Nasional Pendidikan (SNP). Untuk menjadikan kepala sekolah yang sesuai dengan harapan tersebut, maka pemerintah telah mengeluarkan Permendikbud No 6 Tahun 2018 tentang penugasan guru sebagai kepala sekolah. Dalam permendikbud tersebut sudah diatur mekanisme pengangkatan kepala sekolah sebagai berikut: 1)Pemerintah Provinsi atau kabupaten mengusulkan bakal calon kepala sekolah yang telah lolos administrasi kepada LPPKS untuk diadakan seleksi subtansi, 2)Bakal calon kepala sekolah yang lolos subtansi akan diadakan Pendidikan dan pelatihan, 3)LPPKS bekerja sama dengan lembaga pendidikan dan pelatihan, 4)Calon kepala sekolah yang lulus mendapatkan Surat Tanda Tamat Pendidikan dan Pelatihan sebagai syarat menjadi kepala sekolah. Dalam STTPL tersebut terdapat NUKS ( Nomor Unik Kepala Sekolah ), 5)NUKS inilah yang akan dijadikan dasar dalam pemberian Tunjangan Kinerja Kepala sekolah nantinya.

Dengan diadakannya Pendidikan dan Pelatihan penguatan Kepala Sekolah khususnya sekolah dasar diharapkan dapat memenuhi harapan kita bersama dalam rangka peningkatan mutu sekolah terutama kinerja guru dalam melaksanakan kegiatan belajar mengajar yang merupakan inti dari Pendidikan.

Selain faktor kepemimpinan (kepala sekolah), faktor lain yang mempengaruhi kinerja guru adalah iklim sekolahi. Berdasarkan hasil wawancara dengan beberapa guru, menyatakan bahwa masih terlihat nuansa dibeberapa sekolah yang lingkungan sekolahnya belum kondusif (aman, nyaman dan harmonis) seperti kepala sekolah kurang bekerjasama dengan guru dalam karyawan, kepala sekolah bertindak otoriter, antar guru tidak rukun, adanya intimidasi dari warga terhadap sekolah dan belum adanya kompensasi dan reward dari sekolah kepada guru dan karyawan.

Berdasarkan paparan-paparan di atas, maka dipandang perlu dilakukan penelitian tentang kinerja guru yang berhubungan dengan variabel pendidikan dan pelatihan penguatan kepala sekolah dan iklim sekolah pada sekolah dasar yang ada di wilayah Kecamatan Winong, Kabupaten Pati.

Adapun permasalahan kinerja guru sekolah dasar di Kecamatan Winong yang akan diteliti hanya berkenaan dengan faktor penerapan materi pendidikan dan pelatihan penguatan kepala sekolah di sekolah serta iklim sekolah atau suasana lingkungan kerja di sekolah yang dialami oleh guru. Kedua faktor ini dianggap sebagai faktor yang sangat berhubungan dengan kinerja guru di Sekolah Dasar Negeri yang ada di Kecamatan Winong, Kabupaten Pati, dan selanjutnya menjadi variabel dalam penelitian ini.

Adapun tujuan dalam penelitian ini adalah: 1)Menganalisis besarnya pengaruh pendidikan dan pelatihan penguatan kepala sekolah terhadap kinerja guru pada Sekolah Dasar Negeri di Kecamatan Winong, Kabupaten Pati. 2)Menganalisis besarnya pengaruh iklim sekolah terhadap kinerja guru pada Sekolah Dasar Negeri di Kecamatan Winong, Kabupaten Pati. 3)Menganalisis besarnya pengaruh pendidikan dan pelatihan penguatan kepala sekolah dan iklim sekolah secara bersama - sama terhadap kinerja guru pada Sekolah Dasar Negeri di Kecamatan Winong, Kabupaten Pati.

\section{KAJIAN TEORETIS}

\section{Pendidikan dan Pelatihan Penguatan Kepala Sekolah}

Menurut Notoatmodjo (2015:16) pendidikan dan pelatihan adalah upaya untuk mengembangkan sumber daya manusia, terutama untuk mengembangkan kemampuan intlektual dan kepribadian manusia. Penggunaan istilah pendidikan dan pelatihan dalam sebuah institusi atau organisasi biasanya disatukan menjadi diklat (pendidikan dan pelatihan). Hasibuan (2016:70) pendidikan dan latihan sama dengan pengembangan yaitu merupakan proses peningkatan ketrampilan kerja baik teknis maupun menajerial. Pendidikan berorientasi pada pada teori, dilakukan di kelas, berlangsung lama, dan biasanya menjawab why. Latihan beroerientasi pada praktek, dilakukan dilapangan, berlangsung 
singkat, dan biasanya menjawab how. Admodiwirio (1993:3) memberikan definisi pelatihan adalah bagian dari pendidikan yang mengkaitkan proses belajar untuk meningkatkan keterampilan di luar sistem pendidikan yang berlaku dalam waktu yang relatif singkat dan dengan metode yang mengutamakan praktik daripada teori.

Dalam buku Petunjuk Pelaksanaan Pendidikan dan Pelatihan Penguatan Kepala Sekolah yang dikeluarkan oleh Dirjend GTK Kemdikbud (2019) menyatakan bahwa tujuan umumnya adalah untuk memperdalam kemampuan kepala sekolah dalam memimpin dan mengelola satuan pendidikannya, serta memiliki performa sebagai kepala sekolah bagi seluruh warga sekolah. Secara khusus, Pendidikan dan Pelatihan Penguatan Kepala Sekolah bertujuan agar kepala sekolah mampu: 1)memimpin dan mengelola sekolah; 2)menguasai seluruh kompetensi yang harus dimiliki oleh kepala sekolah dalam menjalankan tugasnya; 3)menumbuhkembangkan sikap, pengetahuan, dan keterampilan pada dimensi kompetensi kepribadian, manajerial, kewirausahaan, supervisi, dan sosial; 4)memiliki performa sebagai kepala sekolah yang profesional bagi seluruh warga sekolah; 5)menjadi contoh ketangguhan, optimisme, dan kreatifitas bagi seluruh warga sekolah di satuan pendidikan yang dipimpin; (Dirjend GTK,2019:4)

Untuk mencapai tujuan tersebut terkait materi : 1)Manajerial meliputi; Teknik Analisis Manajemen; Pengembangan RKS-RKAS, Pengelolaan Kurikulum, Pengelolaan Keuangan, Pengelolaan PTK, Pengelolaan Peserta Didik dan Pengelolaan Sarana Prasarana, 3)Kewirausahaan meliputi; Pengantar dan Konsep Kewirausahaan dan Pengembangan Kewirausahaan, 3)Supervisi Guru dan Tenaga Kependidikan, 4)Kepemimpinan meliputi; Kepemimpinan Pembelajaran dan Kepemimpinan Perubahan, 5)Pengembangan Sekolah Berdasarkan 8 SNP

Diharapkan setelah mengikuti Pendidikan dan pelatihan penguatan kepala sekolah dapat menerapkan kompetensi yang didapatkannya dalam melaksanakan tugas di sekolah masing masing. Setelah sampai ditempat tugas masing masing harus ada perubahan perilaku, kinerja maupun kebijakan yang mencerminkan implementasi dari kegiatan Pendidikan dan pelatihan penguatan kepala sekolah tersebut

\section{Iklim Sekolah}

Menurut Daryanto dan Farid (2013:221) iklim sekolah ialah istilah luas yang mengacu pada persepsi guru dari lingkungan kerja umum dari sekolah, organisasi formal, organisasi non formal, peran peserta, dan pengaruh kepemimpinan organisasi itu. Sederhananya, iklim sekolah merupakan karakteristik yang membedakan satu sekolah dari yang lain dan pengaruh perilaku anggota masing- masing sekolah ialah iklim organisasi sekolah. Lebih khusus iklim sekolah adalah kualitas yang relatif abadi dari lingkungan sekolah yang dialami peserta, mempengaruhi perilaku mereka, dan didasarkan pada persepsi kolektif perilaku mereka di sekolah.

Hoy dan Miskel (2014:313) berpendapat bahwa iklim sekolah merupakan sebuah terma luas yang merujuk pada persepsi guru tentang lingkungan kerja umum sekolah, organisasi formal, organisasi non formal, kepribadian para partisipan, dan kepemimpinan organisasional mempengaruhinya. Dengan kata lain, serangkaian karakteristik internal yang membedakan sekolah satu dengan sekolah lainnya dan mempengaruhi perilaku anggota dari masing- masing sekolah. Lebih spesifik lagi iklim sekolah merupakan suatu kualitas lingkungan sekolah yang relatif tetap yang dialami oleh para partisipan, mempengaruhi perilaku mereka, dan didasarkan pada persepsi kolektif mereka tentang perilaku di sekolah.

Dapat disimpulkan bahwa iklim sekolah adalah kondisi lingkungan sekolah yang dirasakan secara langsung maupun tidak langsung oleh komponen sekolah dalam melaksanakan tugas di sekolah. Dengan kata lain iklim sekolah dapat digambarkan sebagai suatu kualitas situasi dan kondisi, peristiwa, maupun keadaan di sekolah yang mempengaruhi kerja personil didalamnya, baik individu dan kelompok dalam lingkungan sekolah dalam mencapai tujuan sekolah yang telah ditetapkan secara bersama, yang menggambarkan tanggung jawab, tugas dan peran masing-masing, dukungan kerja yang diberikan, dan hubungan antar personil di sekolah. 


\section{Kinerja Guru}

Mangkunegara, Anwar A (2006:67) yang menyatakan bahwa Kinerja (prestasi kerja) adalah hasil kerja secara kualitas dan kuantitas yang dicapai oleh seorang pegawai dalam melaksanakan tugasnya sesuai dengan tanggug jawab yang diberikan kepadanya. Sedaangkan Samsudin (2006:159) yang memberikan pengertian kinerja sebagai tingkat pelaksanaan tugas yang dapat dicapai seseorang dengan menggunakan kemampuan yang ada dan batasan-batasan yang telah ditetapkan untuk mencapai tujuan organisasi. Pendapat ini didukung oleh Nawawi (2005:234) yang memberikan pengertian kinerja sebagai hasil pelaksanaan suatu pekerjaanyang memberikan pema- haman bahwa kinerja merupakan suatu perbuatan atau perilaku seseorang yang secara langsung maupun tidak langsung dapat diamati oleh orang lain. Mulyasa (2012:136) yang mendefinisikan kinerja sebagai prestasi kerja, pelaksanaan kerja, pencapaian kerja, hasil kerja atau unjuk kerja.

Berdasarkan beberapa definisi yang dikemukakan di atas, dapat dinyatakan bahwa kinerja guru merupakan prestasi yang dicapai oleh seseorang guru dalam melaksanakan tugasnya atau pekerjaannya selama periode tertentu sesuai standar kompetensi dan kriteria yang telah ditetapkan untuk pekerjaan tersebut. Kinerja seorang guru tidak dapat terlepas dari kompetensi yang melekat dan harus dikuasai. Kompetensi guru merupakan bagian penting yang dapat menentukan tingkat kemampuan guru dalam melaksanakan tugasnya sebagai seorang pengajar yang merupakan hasil kerja dan dapat diperlihatkan melalui suatu kualitas hasil kerja, ketepatan waktu, inisiatif, kecepatan dan komunikasi yang baik.

\section{METODE PENELITIAN}

Penelitian ini dirancang dengan menggunakan pendekatan kuantitatif dan merupakan jenis penelitian korelasional. Data yang digunakan untuk menganalisis perilaku yang menyangkut pendidikan dan latihan penguatan kepala sekolah, iklim sekolah, dan kinerja guru diperoleh melaluli metode pengumpulan data dengan mengambil sampel dari suatu populasi dan menggunakan kuesioner sebagai alat pengumpulan data. Desain penelitian ini sebagaimana digambarkan pada bagan berikut ini.

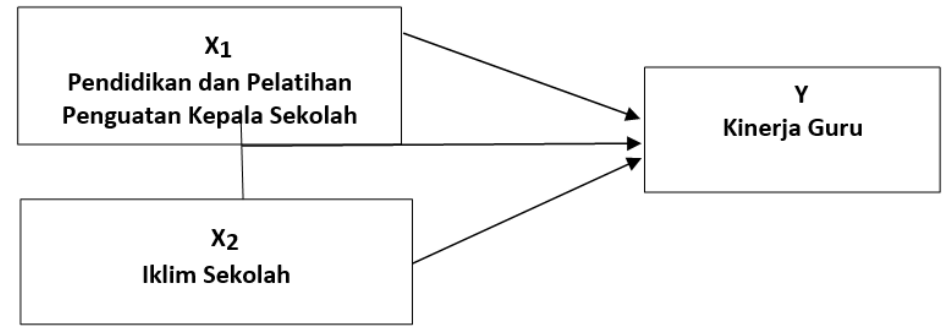

\section{Gambar 1. Desain Penelitian}

Populasi dalam penelitian ini adalah seluruh Sekolah Dasar Negeri di Kecamatan Winong, Kabupaten Pati yang berjumlah 167 guru. Penentuan sampel untuk guru dilakukan dengan menggunakan rumus Taro Yamane atau Slovin dalam Ridwan (2005:65). Rumus dimaksud adalah sebagai berikut: $\quad \mathrm{n}=\frac{N}{N^{d 2}+1}$ dengan presisi atau batas toleransi kesalahan pengambian sampel yang digunakan (0.05). Jumlah sampelnya adalah 160 guru.

Instrumen yang digunakan dalam penelitian ini adalah kuesioner dengan menggunakan skala Likert dengan lima pilihan jawaban dari yang sangat positif sampai sangat negatif dengan gradasi nilai mulai dari 1-5. Untuk memperoleh data dalam penelitian ini digunakan alat pengumpul data utama berupa angket (kuesioner) yang berisi sejumlah pertanyaan/ pernyataan tertulis. Untuk memudahkan dalam pengisian dan pengumpulan data maka dibuat dalam link Google form. Untuk uji coba intrumens, penulis melaksanakan pada 26 guru yang ada di Gugus Sekolah KH Agus Salim Kecamatan Tambakromo Kabupaten Pati. Dari hasil uji coba intrument penelitian kemudian dianalisis validitas 
dan realibilitanya dengan menggunakan aplikasi pengolahan data SPSS versi 16,0 .

\section{HASIL DAN PEMBAHASAN}

Hasil analisis regresi sederhana menunjukkan bahwa model hubungan pendidikan dan pelatihan penguatan kepala sekolah terhadap kinerja guru dinyatakan dengan persamaan $\mathrm{Y}=$ $71.661+0.632 \mathrm{X}_{1}$. Berdasarkan tabel Anova diketahui bahwa nilai $\mathrm{F}$ sebesar 15.224 dengan signifikansi $0.000 \leq 0.05$ jadi model regresi signifikan yang berarti model hubungan pendidikan dan pelatihan penguatan kepala sekolah dengan kinerja guru persamaan regresi $\mathrm{Y}$ $=71.661+0.632 \mathrm{X}_{1}$ signifikan atau diterima kebenarannya. Dengan demikian dapat dimaknai bahwa setiap kenaikan satu satuan pendidikan dan pelatihan penguatan kepala sekolah akan menaikkan kinerja guru sebesar 0.632 pada konstanta 71.661.

Adapun kekuatan hubungan antara pendidikan dan pelatihan penguatan kepala sekolah dengan kinerja guru dinyatakan dengan koefisien korelasi product moment sebesar 0.685. Karena nilai sig. (2-tailed) $\leq 0.05)$, maka terdapat hubungan yang signifikan antara variabel pendidikan dan pelatihan penguatan kepala sekolah dengan kinerja guru. Artinya semakin tinggi pendidikan dan pelatihan penguatan kepala sekolah semakin tinggi pula kinerja guru. Besarnya kontribusi antara variabel pendidikan dan pelatihan penguatan kepala sekolah terhadap variabel kinerja guru adalah sebesar 0.896 atau sebesar $89.6 \%$. Hasil temuan ini membuktikan adanya pengaruh yang positif dan signifikan dari pendidikan dan pelatihan penguatan kepala sekolah terhadap variabel kinerja guru, pendidikan dan pelatihan penguatan kepala sekolah memiliki peran penting dalam meningkatkan kinerja guru.

Hasil analisis regresi sederhana menunjukkan bahwa model hubungan iklim sekolah terhadap kinerja guru dinyatakan dengan persamaan $\mathrm{Y}=71.661+0.495 \mathrm{X}_{2}$. Berdasarkan tabel anova diketahui bahwa nilai $F$ sebesar 14.152 dengan signifikansi $0.000 \leq 0.05$ jadi model regresi signifikan yang berarti model iklim sekolah terhadap kinerja guru dinyatakan dengan $\mathrm{Y}=$ $71.661+0.495 \mathrm{X}_{2}$ signifikan atau diterima kebenarannya. Dengan demikian dapat dimaknai bahwa setiap kenaikan satu satuan iklim sekolah akan menaikkankinerja guru sebesar 0.495 pada konstanta 71.661.

Adapun kekuatan hubungan antara iklim sekolah dan kinerja guru dinyatakan dengan koefisien korelasi product moment sebesar 0.697. Karena nilai sig. (2-tailed) $=0.00 \leq 0.05$, maka terdapat hubungan yang signifikan antara variabel iklim sekolah dankinerja guru. Artinya semakin baik iklim sekolah maka akan semakin tinggi tingkat kinerja guru. Besarnya kontribusi antara variabel iklim sekolah dan kkinerja guru adalah sebesar 0.744 atau sebesar $74.4 \%$.

Berdasarkan data di atas, maka temuan dari hasil penelitian ini menunjukkan bahwa terdapat pengaruh positif dan signifikan antara iklim sekolah dengan kinerja guru- guru SD Negeri di Korwil Pendidikan Kecamatan Winong Kabupaten Pati.

Hasil temuan per indikator diperoleh data tentang iklim sekolah sebagai berikut: hubungan antara atasan dengan bawahan dan keterlibatan dan partisipasi masuk dalam kategori sedang. Sedangkan hubungan atara sesama anggota organisasi/ sekolah kategori tinggi, tanggung jawab, imbalan, struktur kerja kategori tinggi.

Hasil analisis regresi ganda antara pendidikan dan pelatihan penguatan kepala sekolah dan iklim sekolah terhadap kinerja guru dapat diketahui bahwa model pendidikan dan pelatihan penguatan kepala sekolah dan iklim sekolah terhadap kinerja guru dinyatakan dengan persamaan :

$$
\hat{\mathrm{Y}}=71.661+0.632 \mathrm{X}_{1}+0.495 \mathrm{X}_{2}
$$

Berdasarkan tabel anova diketahui bahwa nilai $F$ sebesar 71.661 dengan signifikansi $0.000 \leq$ 0.05 jadi model regresi signifikan yang berarti model hubungan antara pendidikan dan pelatihan penguatan kepala sekolah dan iklim sekolah terhadap kinerja guru dengan pesamaan regresi $\hat{Y}$ $=71.661+0.632 \mathrm{X}_{1}+0.495 \mathrm{X}_{2}$. diterima kebenarannya. Dengan demikian dapat dimaknai bahwa setiap kenaikan satu satuan pendidikan pelatihan penguatan kepala sekolah dan iklim sekolah akan meningkatkan kinerja guru sebesar 20.4 pada konstanta 71.661.

Adapun kekuatan hubungan antara pendidikan pelatihan penguatan kepala sekolah dan iklim sekolah akan terhadap kinerja guru yang 
diperoleh dari analisis korelasi ganda sebesar 0.796. Jadi korelasi antara pendidikan pelatihan penguatan kepala sekolah dan iklim sekolah akan terhadap kinerja guru secara bersama-sama signifikan, artinya semakin tinggi pendidikan pelatihan penguatan kepala sekolah dan iklim sekolah akan, semakin tinggi pula tingkat kinerja guru. Besarnya kontribusi antara pendidikan pelatihan penguatan kepala sekolah dan iklim sekolah akan terhadap kinerja guru sebesar 0.796 atau $79.6 \%$ sedangkan sisanya $20.4 \%$ dipengaruhi oleh variabel yang lain.

Secara garis besar hasil temuan penelitian ini terdapat pengaruh positif dan signifikan antara pendidikan pelatihan penguatan kepala sekolah dan iklim sekolah akan terhadap kinerja guru SD Negeri di Kecamatan Winong Kabupaten Pati. pendidikan pelatihan penguatan kepala sekolah memberikan kontribusi sebesar $89.6 \%$ terhadap iklim sekolah memberikan kontribusi sebesar 74.4\% terhadap kinerja guru SD Negeri di KecamatanWinong Kabupaten Pati. Sedangkan pendidikan pelatihan penguatan kepala sekolah dan iklim sekolah secara bersama-sama memberikan kontribusi sebesar $79.6 \%$ terhadap kinerja guru SD Negeri di Kecamatan Winong Kabupaten Pati.

\section{SIMPULAN DAN REKOMENDASI}

Dari hasil perhitungan uji $\mathrm{F}$ diperoleh hasil yaitu $\mathrm{F}$ hitung sebesar 19.124 dengan tingkat signifikansi $5 \%$ dibandingkan dengan $\mathrm{F}$ Tabel dengan df $(160-2-1=157)$ sebesar 3.05 Maka $F$ hitung > F tabel sehingga dapat disimpulkan ada pengaruh yang signifikan pendidikan dan pelatihan penguatan kepala sekolah (X1) dan iklim sekolah (X2) terhadap kinerja guru (Y). Hal ini dapat dimaknai bahwa setiap kenaikan satu satuan pendidikan dan pelatihan penguatan kepala sekolah dan iklim sekolah akan menaikkan kinerja guru sebesar 20.4 pada konstanta 71.661, dengan demikian hipotesis yang diajukan diterima.

Berdasarkan hasil penelitian dan pembahasan maka dapat disimpulkan sebagai berikut: 1) Ada pengaruh pendidikan dan pelatihan penguatan kepala sekolah terhadap kinerja guru SD Negeri di Kecamatan Winong Kabupaten Pati. Pengaruh tersebut sebesar 63.2\%. Semakin tinggi pendidikan dan pelatihan penguatan kepala sekolah semakin tinggi pula kinerja guru. 2) Ada pengaruh iklim sekolah terhadap kinerja guru SD Negeri di Kecamatan Winong Kabupaten Pati. Besar pengaruh tersebut adalah 49.5\%. Semakin tinggi iklim sekolah semakin tinggi pula kinerja guru. 3)Ada pengaruh antara pendidikan dan pelatihan penguatan kepala sekolah dan iklim sekolah sekolah secara bersamasama terhadap kinerja guru SD Negeri di Kecamatan Winong Kabupaten Pati. Besar pengaruh pendidikan dan pelatihan penguatan kepala sekolah dan iklim sekolah adalah $20.4 \%$. Semakin tinggi pendidikan dan pelatihan penguatan kepala sekolah dan iklim sekolah makin tinggi pula tingkat kinerja guru.

\section{DAFTAR PUSTAKA}

Agustina. (2016). Pengaruh Kepemimpinan Kepala Sekolah, Iklim Sekolah, dan Kinerja Guru Terhadap Mutu Pendidikan Di SMP Negeri Kecamatan Terbanggi Besar Kabupaten Lampung Tengah. tesis. Bandar Lampung. Program Sarjana FKIP Universitas Lampung Bandar Lampung.

Aghniya, H. (2017). Kinerja Kepala Sekolah dan Kinerja Mengajar Guru dalam Peningkatan Mutu Sekolah Dasar Negeri. Jurnal Administrasi Pendidikan, XXIV(1). 17-25.

Arikunto, S. (2010). Prosedur Penelitian Suatu Pendekatan Praktik. Jakarta : PT. Rineka Cipta.

Basri, A. F. M., dan Rivai, V. (2005). Performance appraisal. Jakarta: PT Raja. Grafindo Persada.

Chirkina, T. A, \& Khavenson, T. E. (2018). School Climate A History Of The Concept And Approaches To Defining And Measuring It On Pisa Questionnaires. Russian Education \& Society Journal, 60(2), 133160.

Dirjend GTK. (2019). Petunjuk Pelaksanaan Pendidikan dan Pelatihan Penguatan Kepala Sekolah. Jakarta : Departemen Pendidikan dan Kebudayaan

Dedeh, S. H. (2010). Pengaruh Pendidikan Latihan (Diklat) Kepemimpinan Guru Dan Iklim Kerja Terhadap Kinerja Guru Sekolah Dasar Se- Kecamatan Babakancikao 
Kabupaten Purwakarta. Jurnal Penelitian Pendidikan, 11(2), 85 - 96

Emu, W. H. (2018). Management Of School Climate And Teachers' Job Performance In Secondary Schools In Calabar Education Zone, Cross River State. Global Journal Of Educational Research. 17(-), 127-137.

Erna, W., Murwati, T., \& Raharjo, J. (2018). The Influence Of Principal Leadership, School Culture Through Motivation On Junior High School Teacher Performance. Educational Management UNNES, 7(1), $11-16$.

Evonne, L. E. F., \& Crispina, G. K. H. (2020). The Influence Of School Climate, Teachers' Commitment, Teachers' Motivation On Teachers' Work Performance Through Teachers' Job Satisfaction. International Journal of Advanced Research In Education And Society. 1(3): 23-35

Fatmi, A., Rizki, P., Edi, H., \& Yasir, A. (2018). Influence Of School Principal And Organizational Climate Supervision On Teachers' Performance. International Journal Of Scientific \& Technology Research, 7(7), 228-236.

Hamalik, O. (2005). Pengembangan Sumber Daya Manusia: Manajemen Pelatihan Ketenagakerjaan Pendekatan Terpadu . Jakarta: Bumi Aksara.

Hardjana, A. (2006). Iklim Organisasi: Lingkungan Kerja Manusiawi. Jurnal Ilmu Komunikasi, 3(1), 20-30.

Husnul, A. (2017). Kinerja Kepala Sekolah Dan Kinerja Mengajar Guru Dalam Peningkatan Mutu Sekolah Dasar Negeri. Jurnal Administrasi Pendidikan, XXIV (1), $25-35$

Hoy, W. K. dan Miskel, C. G. (2014). Educational Adminitration: Teory, Research, and Practice. New York: McGraw-Hill Companies, Inc.

Imas, S., Bukman, L., \& Dessy, W. (2020). The Influence Of Principal's Leadership And Teacher's Performance On Student' Achievement. International Journal of Progressive Sciences And Technologies (IJPSAT). 20(1), 247-254.
Komariah dan Triatna. (2006). Visionery Leadership menuju Sekolah Efektif. Jakarta: PT Bumi Aksara.

Lazarus, N. M. (2011). School Climate and Academic Performance in High and Low Achieving Schools: Nandi Central District, Kenya. International Journal of Scientific Research in Education, 4(2), 93-104

Luis, A. G., \& Wayan, G. S. (2016). Pengaruh Gaya Kepemimpinan Dan Motivasi Kerja Terhadap Kinerja Guru. E-Jurnal Ekonomi Dan Bisnis Universitas Udayana, 5 (3), 429-454.

Loukas, A. (2007). What is School Climate?. Jurnal : The University of Texas at Austin.

Mangkunegara, A. P., (2006). Manajemen Sumber Daya Manusia Perusahaan. Bandung: PT. Remaja Rosdakarya

Mudena, S. \& Wilian, S. (2017). Pengaruh Komunikasi Kepala Sekolah Dan Iklim Kerja Organisasi Sekolah Terhadap Kinerja Guru Sd Negeri Di Kecamatan Mataram Kota Mataram. Jurnal Ilmiah Profesi Pendidikan, 2(1), $71-83$.

Mukhtar dan Iskandar. (2009). Orientasi Baru Supervisi Pendidikan. Jakarta: Gaung Persada.

Mukhlisoh, N. (2008). Pengaruh Pendidikan dan Pelatihan kompetensi kepala Sekolah, Kompensasi dan Kepuasan Kerja Guru Terhadap Kinerja Guru Madrasah Tsanawiyah Swasta Kecamatan Bulakamba Brebes. tesis. Semarang: Program Pasca Sarjana Program Studi Manajemen Pendidikan UNNES

Muhammad, F., Syafrudin., \& Joni, R. (2018). Principal's Managerial Skill In Improving Teachers' Performance. IOSR Journal of Research \& Method in Education (IOSRJRME), 8(3), 77-81.

Mulyasa. (2013). Menjadi Kepala Sekolah Profesional. Bandung: PT Remaja Rosdakarya.

Notoatmodjo, S. (2015). Pengembangan Sumber Daya Manusia, Jakarta: Rineka Cipta

Nurkolis. (2006). Manajemen Berbasis Sekolah: Teori, Model dan Aplikasi. Jakarta: PT Grasindo. 
Nur, A. W., Abdullaha, D. D., \& Norlidah, A. (2013). School Improvement Efforts and Challenges: A Case Study of A Principal Utilizing Information Communication Technology. Procedia - Social and Behavioral Sciences, 103 (-), 791 - 800.

Obiajulu, C. E. (2017). Influence of School Climate on Teachers Morale in Public Secondary Schools in Delta State. IOSR Journal of Research \& Method in Education (IOSR-JRME), 7(1), 19-24

Riggle. (2007). The Impact Of Organizational Climate Variables of Perceived Organizational Support, Workplaceisolation, and Ethical Climate on Salesperson Psychological and Behavioral Work Outcomes. Graduate Theses and Dissertations University of South Florida

Samsudin. (2006). Manajemen Sumber Daya Manusia. Bandung Pustaka Setia.

Sinaulan, R. L. (2016). Effect of School Climate, Work Stress and Work Motivation on Performance of Teacher. Guidena Journal, 6(2), 146-153.

Sugiyono. (2015). Metode Penelitian Pendidikan, Bandung : Alfabeta.

Suharsaputra, U. (2010). Administrasi Pendidikan. Bandung: Refika Aditama

Sulistiyanto, E. (2012). Pengaruh Pendidikan dan Latihan, Motivasi Berprestasi terhadap Kinerja Guru Bimbingan dan Konseling Sekolah Menengah Pertama di Kabupaten Jepara. tesis. Semarang: Program Pasca Sarjana Program Studi Manajemen Pendidikan UPGRIS

Sulardi. (2017). Pengaruh Manajemen Berbasis Sekolah Dan Iklim Organisasi Sekolah Terhadap Profesionalitas Guru Smp/Mts Muhammadiyah Di Kabupaten Sorong Provinsi Papua Barat. Jurnal Pendidikan, 5(2), $64-74$.

Sophie, M., Katherine. J. R., Eunro, L., Emina Subasic., \& David, B. (2017). The Impact of School Climate and School Identification on Academic Achievement: Multilevel Modeling with Student and Teacher Data. Frontiers in Psychology, 8(), 1-21
Usman, M U. (2002). Menjadi Guru Profesional. Bandung: PT. Ramaja Rosdakarya.

Utami, S. T. (2016). Pengaruh Iklim Sekolah Terhadap Kinerja Guru di MTs SeKecamatan Kemranjen, Banyumas. tesis. Purwokerto. Program Studi Manajemen Pendidikan Islam Fakultas Tarbiyah dan Ilmu Keguruan Institut Agama Islam Negeri Purwokerto.

Wahjosumidjo. (2003). Kepemimpinan Kepala Sekolah: Tinjuauan Teoritik dan Permasalahannya . Jakarta: Raja Grafindo Persada.

Widyoko, P. E. S. (2012). Teknik Penyusunan Instrumen Penelitian. Yogyakarta: Pustaka Pelajar.

Winda, W. A., \& Reza, R. (2017). Pengaruh Gaya Kepemimpinan Kepala Sekolah Dan Iklim Organisasi Dengan Kinerja Guru Pendidikan Anak Usia Dini. Jurnal Pendidikan Usia Dini, 11 (2), 369-387.

Wresni, P. (2020). Strengthening Of School Quality Through School Principal Leadership. International Journal On Education, Management And Innovation (IJEMI), 1(2), 151-164. 